\title{
Early cave management at the Carrapateena sublevel cave
}

\author{
R Hocking OZ Minerals Limited, Australia \\ G Balog OZ Minerals Limited, Australia \\ T Ormerod OZ Minerals Limited, Australia \\ H Pearce OZ Minerals Limited, Australia
}

\begin{abstract}
Carrapateena is a copper-gold deposit hosted in a brecciated granite complex, located $460 \mathrm{~km}$ north of Adelaide, South Australia. The deposit will be mined by the sublevel cave mining method. The ore is located below $500 \mathrm{~m}$ of unmineralised rock cover with six horizontal domains of various rock strengths, and therefore, fragmentation characteristics. Preliminary testwork of two predominant cover domains has shown that they are likely to break up substantially compared to the ore being mined. Furthermore, the cover sequence hosts two groundwater units of varying permeability which will be intersected by the cave zone.
\end{abstract}

This paper discusses the work in preparation for the mining of the deposit in late 2019, with a focus on:

- Understanding the orebody and cover sequence material.

- Methodologies to understand and manage water ingress into the cave zone.

- Methodology used for modelling of fines ingress.

- Discussion of cave marker placement, and techniques and their purpose.

- Methodologies to obtain the data required to inform safe draw control decisions during ramp-up and mining of the operation.

Keywords: sublevel cave, cave management, mud rush, marker

\section{Introduction}

The Carrapateena project is located in the Gawler craton, in the Olympic Dam province, in South Australia. It is located approximately $460 \mathrm{~km}$ north of Adelaide, South Australia. It is an iron oxide-copper-gold project. In 2017, the feasibility study was approved for a sublevel cave, starting at a depth of $500 \mathrm{~m}$ and mining at a depth to $1,500 \mathrm{~m}$ below the surface. Total ore reserve (as at 2017) is $79 \mathrm{Mt}$ at a grade of $1.8 \% \mathrm{Cu}$ and $0.7 \mathrm{~g} / \mathrm{t}$ $\mathrm{Au}$ (Smith 2017). The overall mine design is shown in Figure 1. Threats associated with understanding fines migration, outlined in this paper, form part of the threats and opportunities identified in the 2017 Carrapateena Feasibility Study Update (OZ Minerals 2017), with this work progressing and improving OZ Minerals' knowledge and control of potential risks.

The deposit will be accessed by a decline and the ore will be transported to the surface by a conveyor belt. The level spacing is $25 \mathrm{~m}$ for the top half of the orebody and $30 \mathrm{~m}$ for the levels in the 2 nd half of the orebody.

The overlying cover consists of a series of flat-lying unaltered quartzites, shales and sandstones which are located as shown in Figure 2. The properties of these rock types vary considerably and need to be considered as part of the mine planning process. 


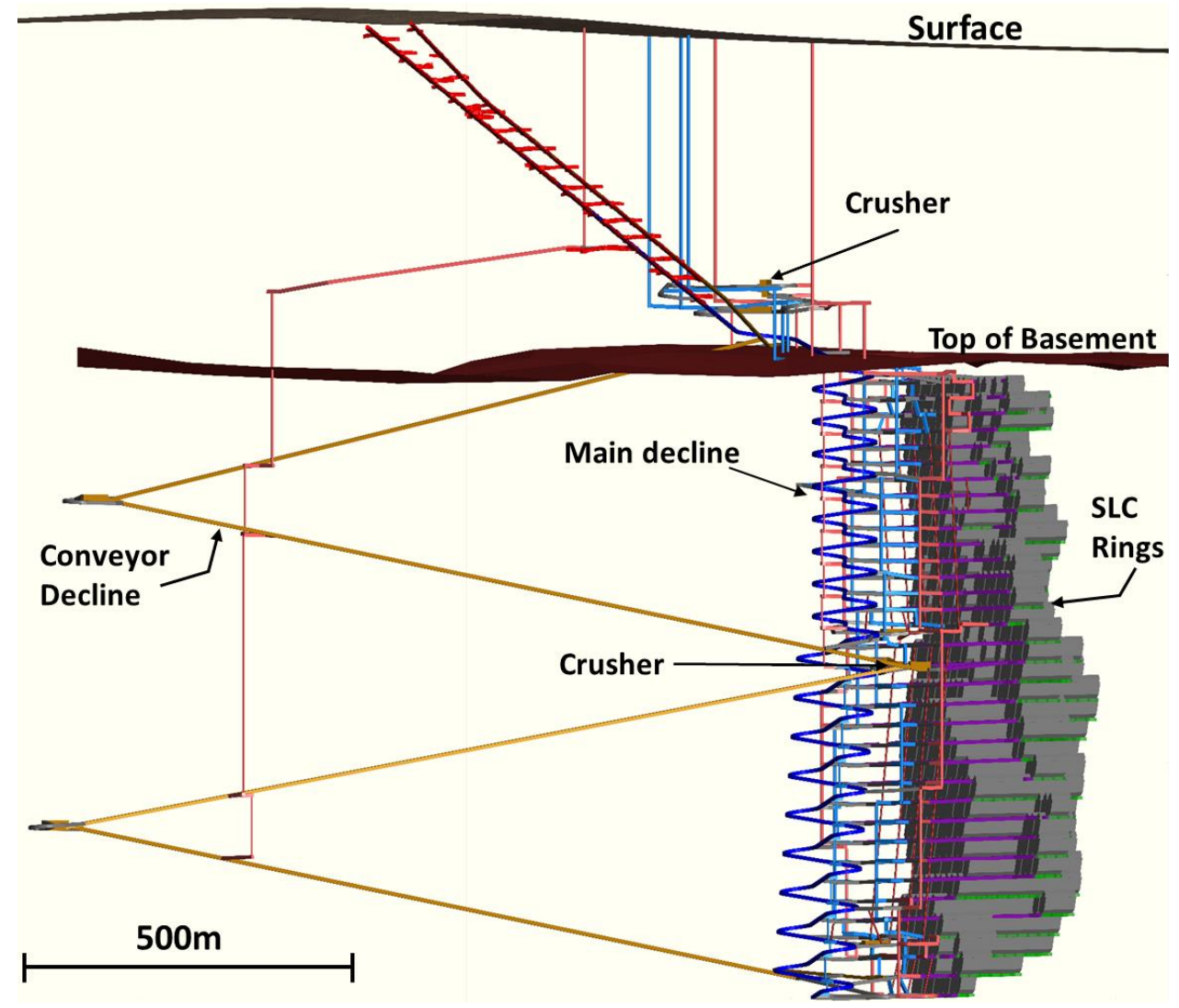

Figure 1 SLC layout of Carrapateena ore deposit

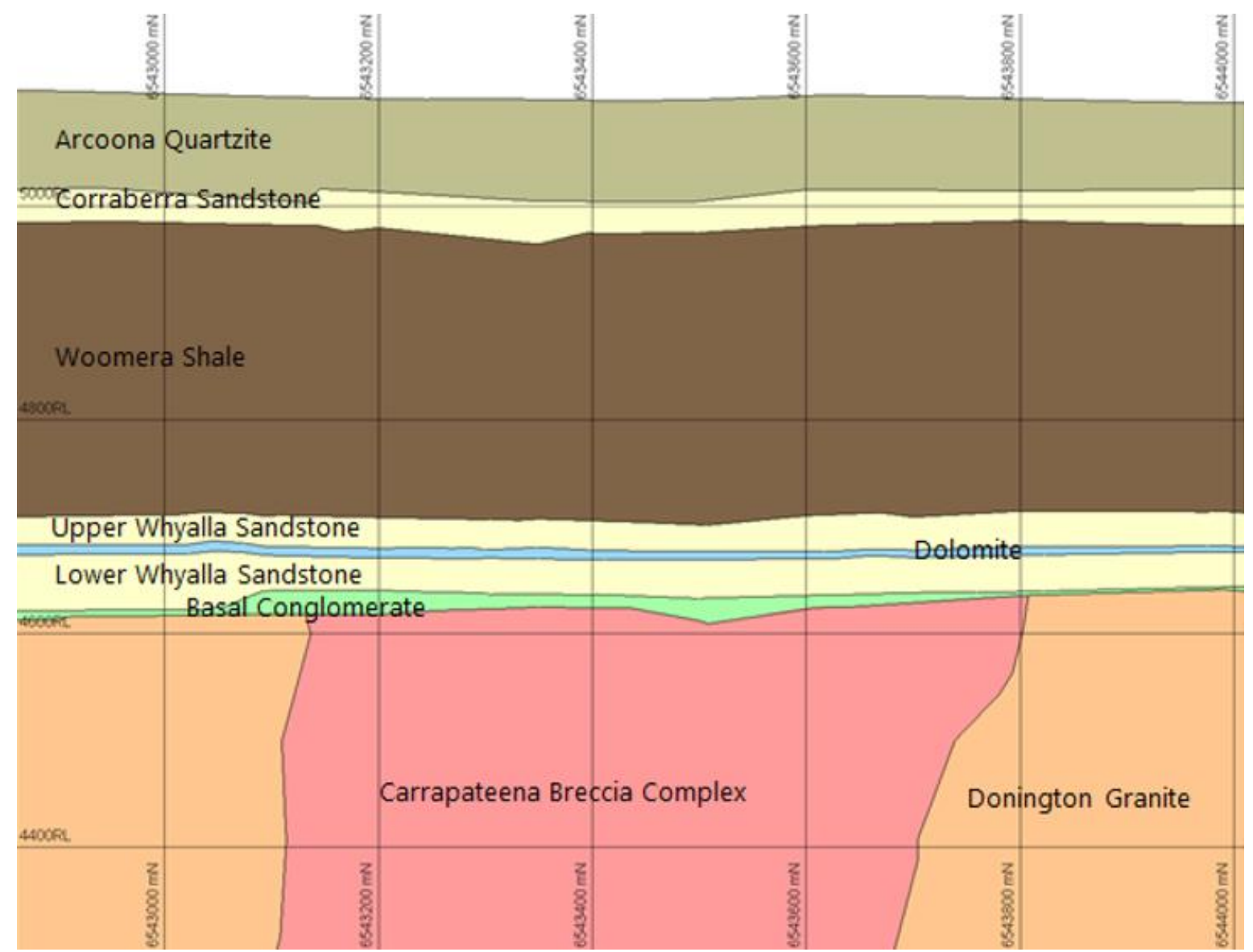

Figure 2 Conceptual layout of the overlying strata at Carrapateena 
Mud rush is the sudden inrush of wet fine material into the mine workings. It is a considerable risk that needs to be mitigated to ensure safe operation of a mine. An uncontrolled mud rush event can likely cause fatalities. Typically, a mud rush is expected if there is a combination of mud forming material made up of material with fine fragmentation, water in the form of rainfall or groundwater, and a triggering mechanism such as uneven draw or a seismic event (Figure 3). Management of mud rush risk is covered by others (Jakubec et al. 2012; Laubscher 2000; Butcher et al. 2005; Regan 2006; Widijanto et al. 2012). In addition to safety concerns, fine material will tend to flow more quickly than coarse material. This means that faster than anticipated dilution can occur through the propagation of fine material. It is therefore important to understand how this fine material propagates.

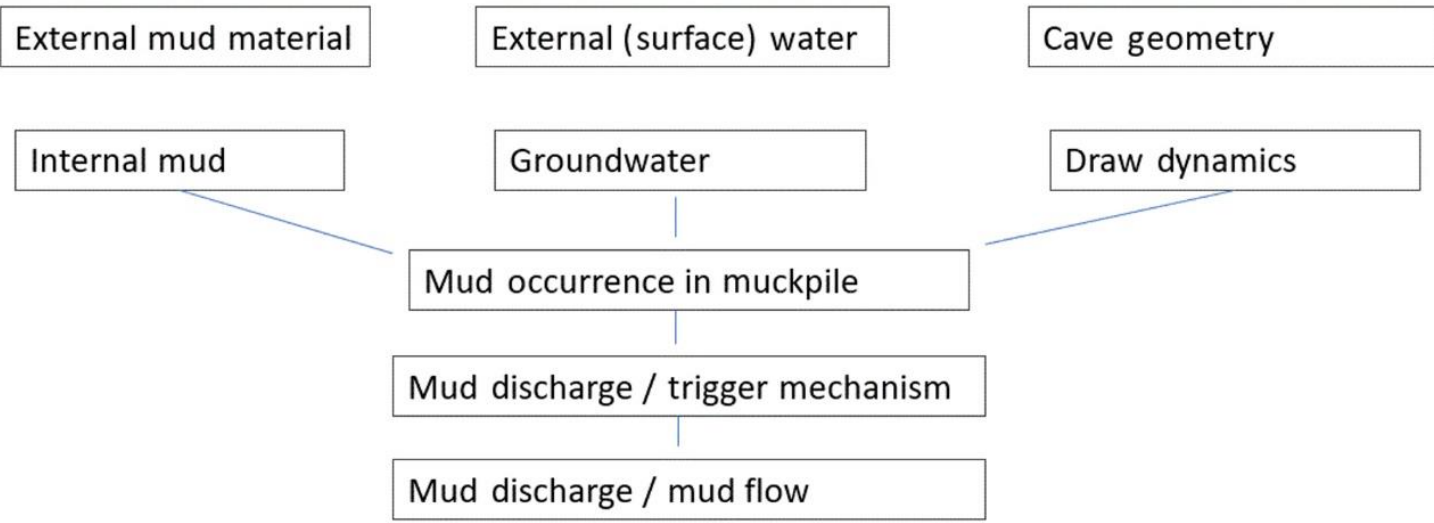

Figure 3 Mechanisms required for mud flow (from Laubscher 2000)

Mud rushes at Freeport (Widijanto et al. 2012) showed that for a mud rush to occur, the following needed to happen: $20 \%$ of material $<2 \mathrm{~mm}$ and a muck pile with $>8.5 \%$ moisture. On the other hand, drawpoints at El Teniente were divided into risk categories dependent on material $<25 \mathrm{~cm}$ in size and moisture content (Vallejos et al. 2017). Despite there being differences in determining the risks of the drawpoints between authors, all agree that it is the combination of fine material, water and a trigger mechanism that can lead to a mud rush event.

For the management of all caving hazards, a careful and detailed monitoring plan needs to be developed to ensure early warning signs can be observed and managed before a major hazard is created. In the case of Carrapateena, the understanding and estimation of fines, their creation through time and their propagation through to the extraction levels needs to be understood before a risk is observed. Therefore, monitoring needs to be in place so that flow models can be calibrated to ensure risk and possible mitigation strategies can be enacted with the data required to make the correct decisions. This paper discusses the potential monitoring strategies and how they can be used to inform and calibrate flow models.

\subsection{Carrapateena cover sequence description}

The Carrapateena Breccia Complex ( $\mathrm{CBC}$ ) hosts the Carrapateena deposit and is overlain unconformably by flat-lying Neoproterozoic sedimentary rocks of the Stuart Shelf. The Stuart Shelf rocks comprise a variety of gritty sandstones, laminated shales, smooth siltstones and locally stromatolitic dolomite. The unconformity between the Stuart Shelf rocks and the CBC is sharp and marked by a poorly sorted, polymictic, coarse-grained, locally termed 'Basal Conglomerate'. Drilling at Carrapateena shows that the Neoproterozoic cover sequence is fairly consistent across the deposit, and no major faulted offsets have been observed.

The geotechnical properties of the cover sequence are varied, ranging from high intact strengths ( $200 \mathrm{MPa})$ and exceptional rock mass quality $(G S I>90)$ to low intact rock strengths ( $<25 \mathrm{MPa}$ ) and low rock mass quality (GSI <40). Cover sequence geotechnical parameters and widths are described in Figure 4. Some slake durability tests were completed, but the average values for the Woomera Shales and Whyalla Sandstone units were above 90 , making them all competent rock masses with this test. 


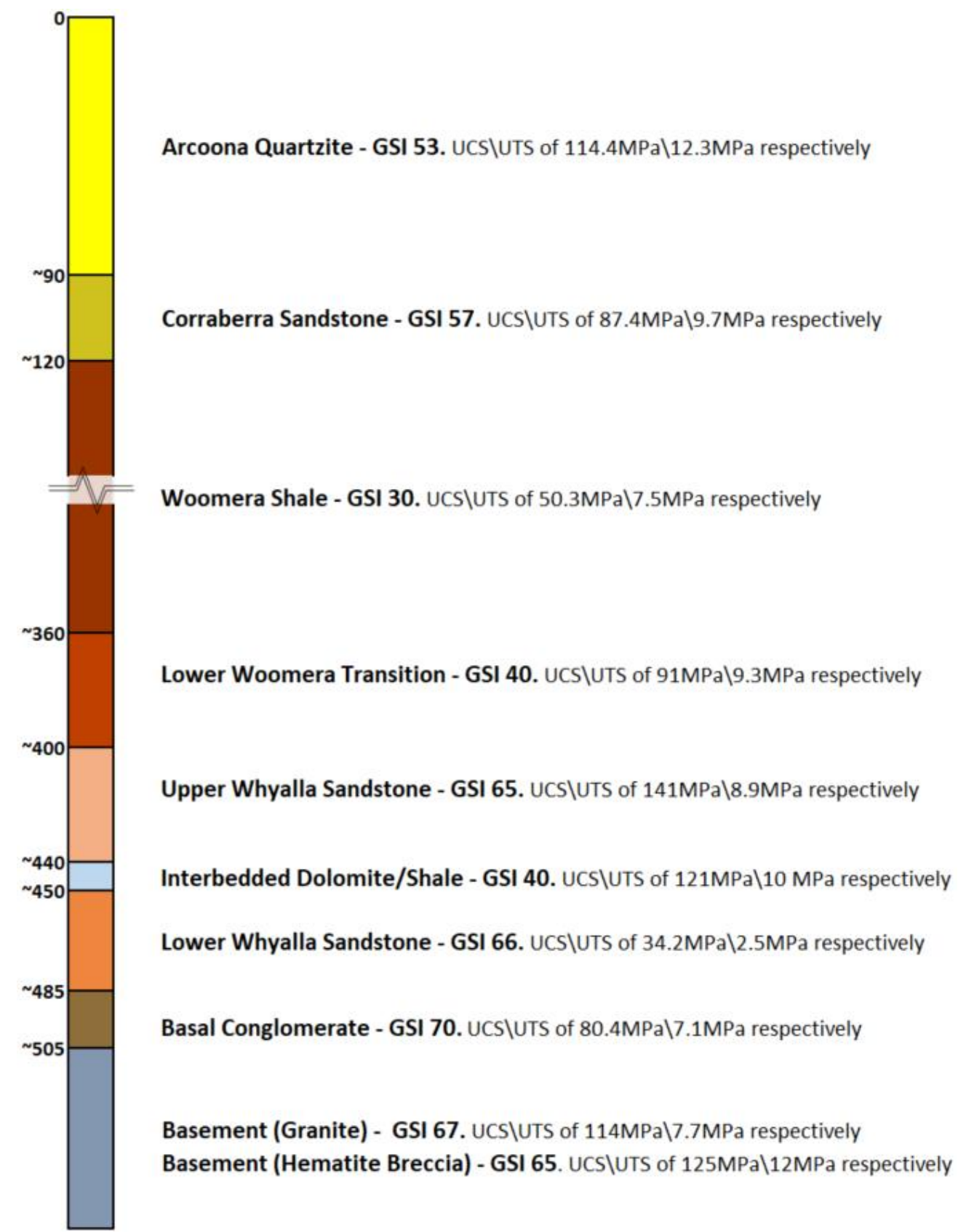

Figure 4 The geotechnical parameters and elevations of cover sequence lithological domains, host granite and hematite breccia

The key domains relevant to this discussion are the lower Whyalla and Shale units with respect to the control of mud rush hazard. Petrographic analysis of the units indicates a high clay fraction to fine-grained silts within the shale, and exclusively gritty aeolian sand grains of a small size fraction within the lower Whyalla Sandstone.

\subsection{Groundwater estimation}

Groundwater investigations have identified two main water sources within the Carrapateena cover sequence; the base of the Corraberra Sandstone (Tent Hill Aquifer; THA) and within the lower Whyalla Sandstone (Whyalla Sandstone Aquifer; WSA). The estimated (modelled) flow rates from investigation wells are high, with peak flow rates combined from the THA and WSA of $80 \mathrm{~L} \backslash \mathrm{s}$ during cave propagation. The THA has been intercepted with development, with observed flow rates averaging $1 \mathrm{~L} \backslash \mathrm{s}$ from a modelled $2 \mathrm{~L} \backslash \mathrm{s}$. The WSA is expected to be intercepted in August 2018, with peak flow rates (modelled) up to $42 \mathrm{~L} \backslash \mathrm{s}$ from development excavations. 
To better understand the long-term flow rates from both aquifers during cave propagation, a monitoring method has been proposed. A network of pre-drilled exploration holes equipped with piezometers will be used to monitor the impact of development excavations as they intersect the WSA. Mine water management includes regular (daily) auditing of mine flow rates, and as such, the excavation flow rate monitoring coupled with nearby piezometers represents an effective and large-scale 'pump test'.

Information gathered from groundwater monitoring will enable long-term hazard assessment of water inflows and necessary response planning. A GoldSim model is planned to be developed to ensure regular auditing of water balances to assess mud rush risk during cave propagation.

\section{Estimation of fines generation in caving mines}

There are several potential measures to estimate fragmentation. However, block cave operations typically focus on coarse fragmentation $>2 \mathrm{~m}^{3}$ (Laubscher 2000). Diering (2016) described fine fragmentation as less than $0.1 \mathrm{~m}$. Within caving, the focus has been on predicting the size of coarse particles, which is less relevant for mud rush estimation. Typical methodologies within mineral processing and size reduction relationships tend to focus on energy reduction relationships with Bond's law, Kick's Law and Rittinger's law typically based on $\mathrm{P}_{80}$, the size of particles that $80 \%$ of the distribution passes through (Napier-Munn et al. 1996).

For description of fine particle size breakage within comminution, Awachie (1983) compared three methods of breakage and found that the particle size distribution could be described by a family of curves. A single $P_{10}$ parameter, describing the material as representing $10 \%$ of the original particle size, was found to be a good description of the finer and coarser particles. Thus, it was determined to represent the fine part of the size distribution well. Naranyanan (1985) then showed that the $t_{10}$ parameter for impact breakage can be fitted to the applied energies to determine the $A$ and $b$ parameters, described by Equation 1 , which can be determined for all rock types:

$$
\mathrm{t}_{10}=\mathrm{A}\left(1-\mathrm{e}^{-\mathrm{b} . \mathrm{Ecs}}\right)
$$

where:

$$
\begin{aligned}
& \mathrm{t}_{10} \quad=\text { the proportion of material }<10 \% \text { of the original particle size. } \\
& \mathrm{E}_{\mathrm{CS}} \quad=\text { the energy applied (in } \mathrm{kWh} / \mathrm{t} \text { ). } \\
& \mathrm{A} \text { and } \mathrm{b}=\text { fitted parameters. }
\end{aligned}
$$

Further research at the Julius Kruttschnitt Mineral Research Centre (JKMRC) developed the abrasion parameter $\left(\mathrm{t}_{\mathrm{a}}\right)$ which was determined though putting $3 \mathrm{~kg}$ of ore in a $300 \mathrm{~mm}$ mill which was tumbled at $53 \mathrm{rpm}$ and then sized, from which a $t_{10}$ parameter was determined (Napier-Munn et al. 1996).

With several different lithologies in the cover sequence, and the potential for this material to travel large distances relative to the ore, an understanding of how the cover material will break up through the muck pile needs to be determined quickly. One of the limitations of testing rock is that while transporting it, it tends to break up. This is a particular consideration for the finely laminated shales and weak lower Whyalla Sandstone. Pierce et al. (2010) created a methodology for determining secondary breakage parameters based on the JKMRC $\mathrm{t}_{10}$ parameter to determine size reduction during impact breakage and parameters within REBOP software (Itasca International, Inc. 2018).

To determine how the different lithologies of the cover sequence break with increasing energy applied, a simple experiment was set up onsite at Carrapateena (Figure 5). Approximately $10 \mathrm{~kg}$ of sample core with a diameter of $60 \mathrm{~mm}$ was placed inside a cement mixer which had a maximum diameter of $710 \mathrm{~mm}$. The material was taken out at 5, 10, 15 and 20 minutes at $22 \mathrm{rpm}$, and the results were sieved. The size distribution was then weighed and recorded. Assuming that the contents of the ore drops $0.4 \mathrm{~m}$ on each revolution, each five minutes of ore movement is equivalent in energy to dropping the ore from a $44 \mathrm{~m}$ height, or $0.12 \mathrm{kWh} /$ tonne. 


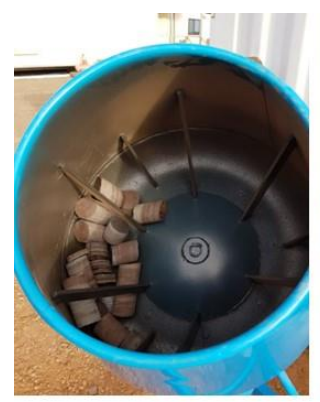

Pre mixing

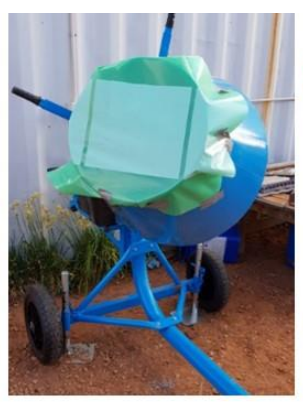

Cover on, ready for mixing

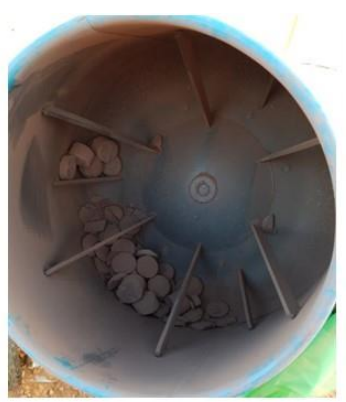

5 minutes

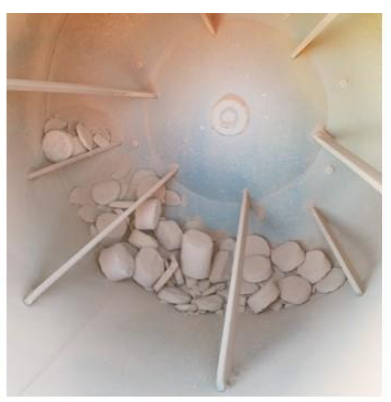

10 minutes

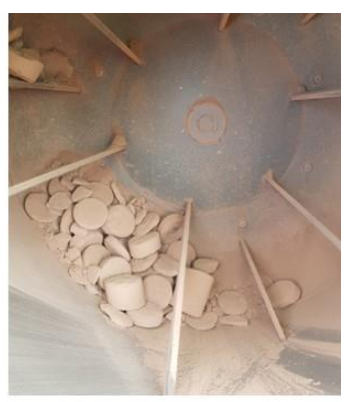

15 minutes

Figure 5 Schematic of the sample preparation and the attrition breakage of the cover sequence of the rocks

\section{$2.1 \quad$ Results}

The breakage behaviour showed a substantial amount of fine material created by the lower Whyalla unit when compared to the other rock types in the cover sequence. Figure 6 shows the total material in the fine $(<1 \mathrm{~mm})$ size fraction for all rock types tested. It can be seen that the lower Whyalla Sandstone broke up considerably more than the other rock types that were tested, with over $70 \%$ of the lower Whyalla sample broken up into the $<1 \mathrm{~mm}$ size fraction.

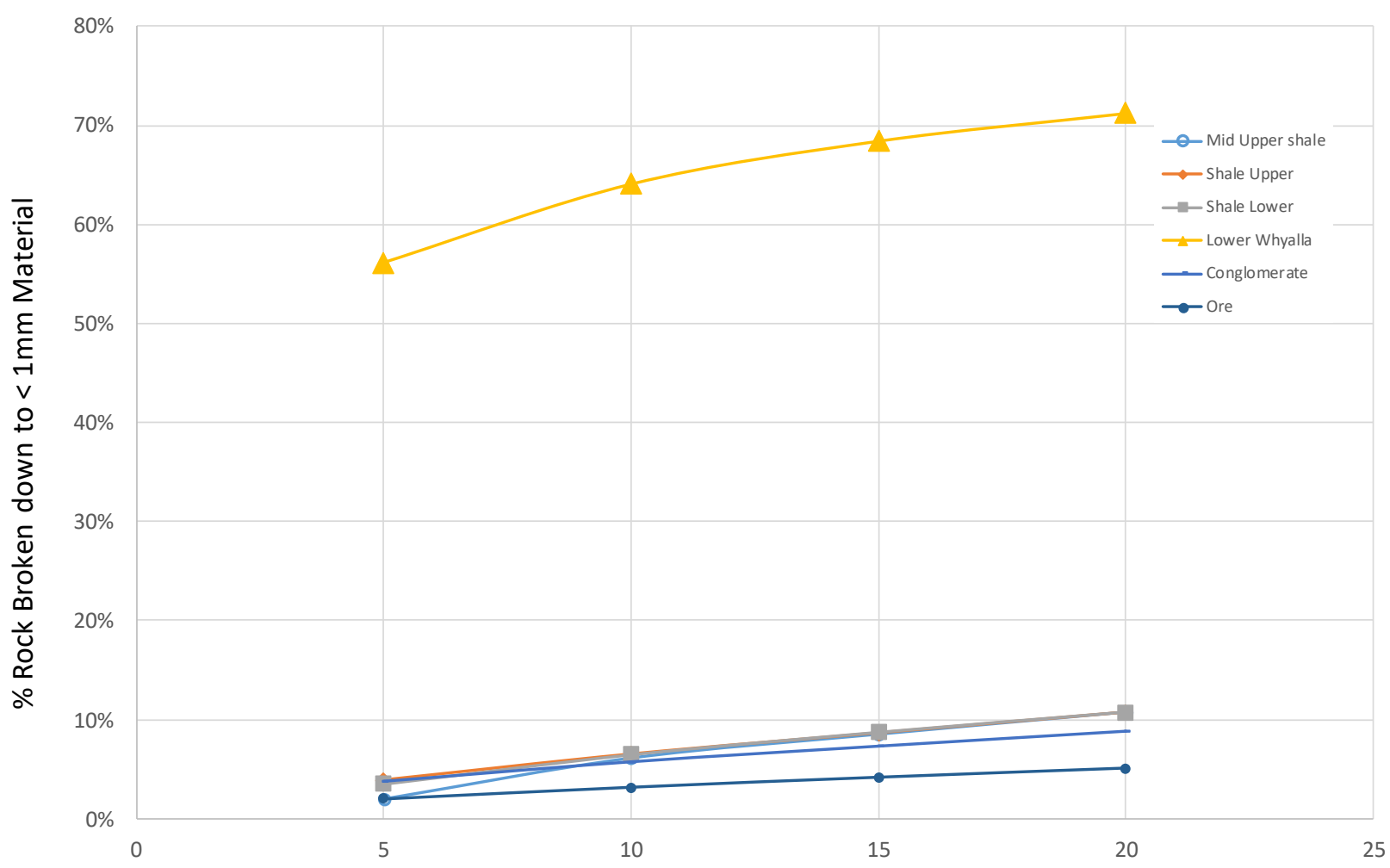

Minutes Material in Cement Mixer

\section{Figure 6 Comparison of size reduction for the cover sequence and ore tested}

The results for the other rocks tested are shown in Figure 7. Figure 7 shows a linear trend of the material generated below $1 \mathrm{~mm}$ for all five rock types that were tested. Each rock type had a statistically significant linear relationship with the time spent in the concrete mixer. 


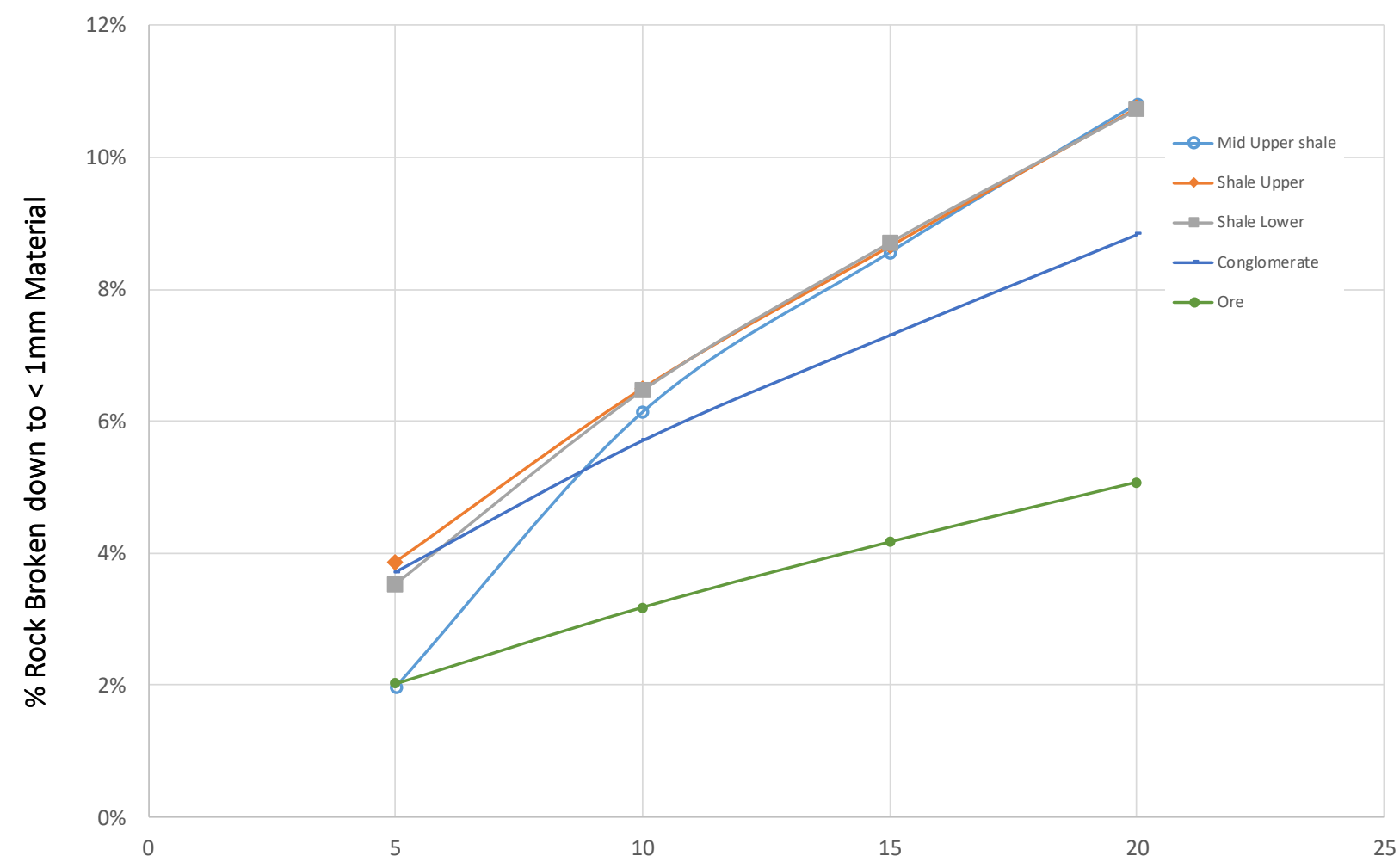

Minutes Material in Cement Mixer

Figure 7 A linear trend is observed between time inside the cement mixer and material in the fine fraction $<1 \mathrm{~mm}$. Similar trends are observed for material $>0.1$ to $10 \mathrm{~mm}$

Table 1 shows the relationship between fine material generated for each rock type and the distance the material needs to travel to the top level of the SLC. The test work discussed above gives a good understanding of how the rock will break down as energy is applied to it in a concrete mixer. Within the cave column, it would be expected that the breakage would occur due to a series of low energy impacts, making this test like the breakage mechanisms within the cave column. Given the large amount of fine fragmentation generated in the lower Whyalla Sandstone unit, for relatively low amounts of energy, the estimation and the measurement of flow from this area is of interest when designing the instrumentation to determine how the fine material will flow within the orebody. While there are potentially more tests that can be done to improve our understanding of how this material breaks up over time, these tests can form a basis for design of the marker program. The shales also produce more fines and have to travel further than the surrounding rock masses. Therefore, further understanding of this material will be important for mud rush management.

Table 1 Comparison of the different rock types for generation of fines

\begin{tabular}{llll}
\hline Rock type & $\begin{array}{l}\text { Percent material }<\mathbf{1 ~} \mathbf{m m} \\
\text { (20 minutes) }\end{array}$ & $\begin{array}{l}\text { Travel distance to } \\
\text { top level SLC }(\mathbf{m})\end{array}$ & $\begin{array}{l}\text { Ratio of fines } \\
\text { fraction }\end{array}$ \\
\hline Ore & 5 & 12.5 & 1 \\
Conglomerate & 9 & 35 & 1.8 \\
Lower Whyalla & 71 & 50 & 14 \\
Shales & 11 & 150 & 2 \\
\hline
\end{tabular}




\subsection{Example of potential flow scenarios}

From the results presented in Section 2.2, it is clear that the lower Whyalla Sandstone unit presents a major risk in terms of the propagation of fine material to the extraction levels. To determine the extent of this, several simulations were run, increasing the speed in which the lower Whyalla Sandstone material flows compared to the surrounding rocks, as these are parameters that can be changed in modelling. It is good to have as many measurements as possible to ensure that the model is being calibrated effectively. There are a few data sources that can be used for calibration of flow to help give a precursor to mud rush issues. These are discussed below.

Power Geotechnical Cellular Automata Code (PGCA) (Power 2018) allows the fines velocity to be varied by allowing the user to adjust the velocity of this material. A series of simulations were run to track the amount of lower Whyalla Sandstone as a total percentage for increasing propagation velocities (Figure 8). These simulations show that in the first couple of years of cave production, there is a strong chance of fine material entering the ore stream. Therefore, early understanding of the mud-forming potential of the lower Whyalla Sandstone material is important for managing safety early in the mine's life.

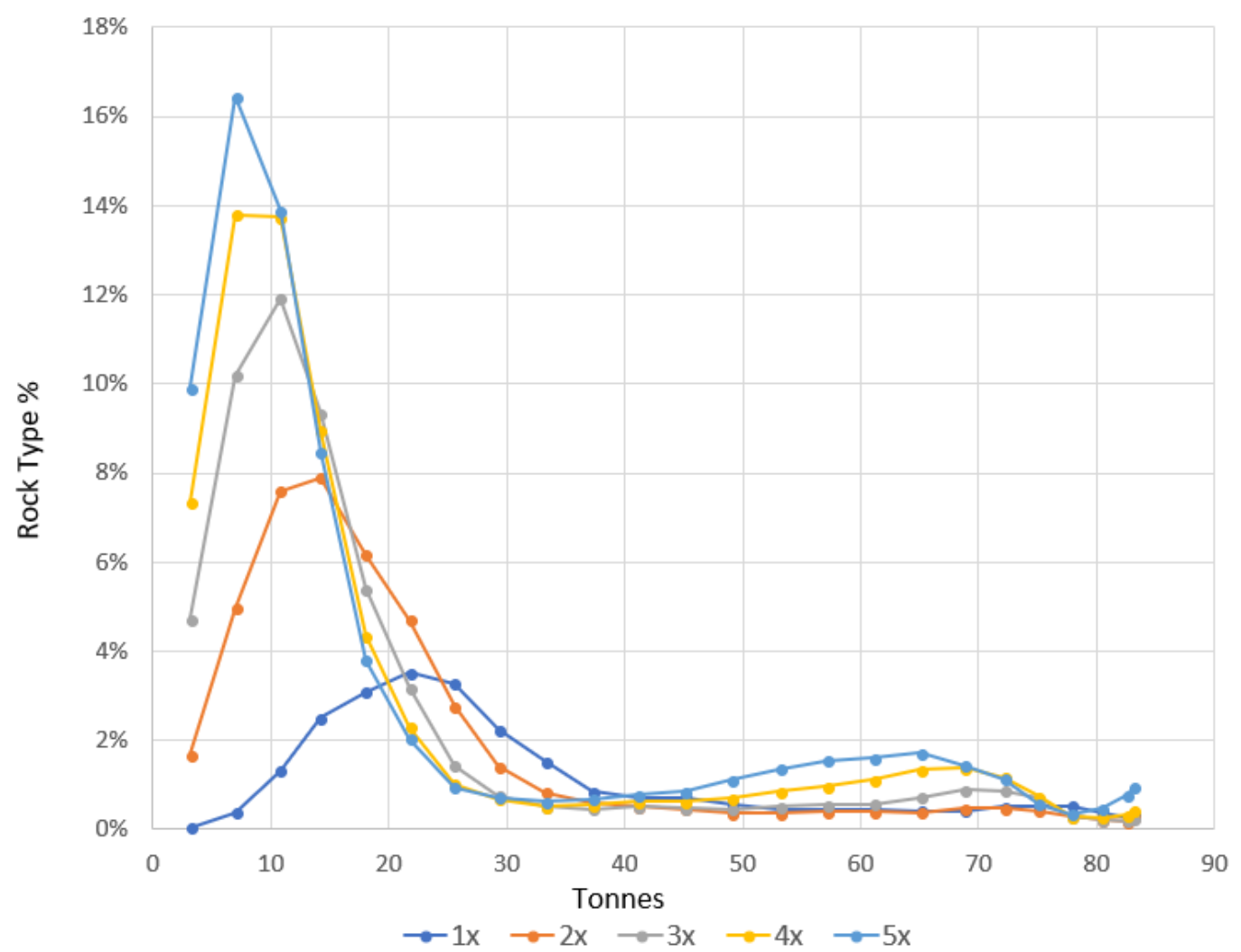

Figure 8 Comparison of different flow velocities and their impact on the likely arrival of lower Whyalla Sandstone

Further work needs to be completed on the Woomera Shale units to determine how this material will propagate through the cave column. 


\section{$3 \quad$ Further work}

The testwork has identified two rock types (lower Whyalla Sandstone and the Woomera Shale) that have a high propensity to produce fine material and have a high prevalence of clays. There are several forward work items that will be required to ensure the safe operation of Carrapateena operating levels. The work consists of three pillars:

- Understanding and placing of markers within the cave to understand flow, and better predict the fines propagation.

- Better understanding of the rock properties.

- Operational readiness through development of the triggered action response plans (TARPs).

\subsection{Planned installation of markers}

Markers are suitable for calibrating models as they are independent of the grade measurements and can be placed at known points in order to calibrate the flow models. They can also be used as important inputs for flow modelling, such as for informing the cave shape that was achieved. A good method for calibrating flow with markers is to populate the markers in the flow package and track how these have come through the flow model. This is achievable in both REBOP and PGCA flow code.

Three types of instrumentation are planned to measure the cave flow behaviour and differentiate the rate of flow of the various cave size fractions. These are Elexon network smart markers, cave tracker markers and beacons, and Metso ore tracker markers.

\subsubsection{Network smart markers}

For global cave growth and large fraction material flow, the Elexon networked smart marker system is to be used. The planned array consists of utilising four boreholes at various orientations; one vertical, and three at a steep angle from outside the cave zone at the hole collar to inside the cave zone (Figure 9). The array serves two purposes; understanding flow within the cave zone and understanding the variance of material flow velocity at the cave boundaries.

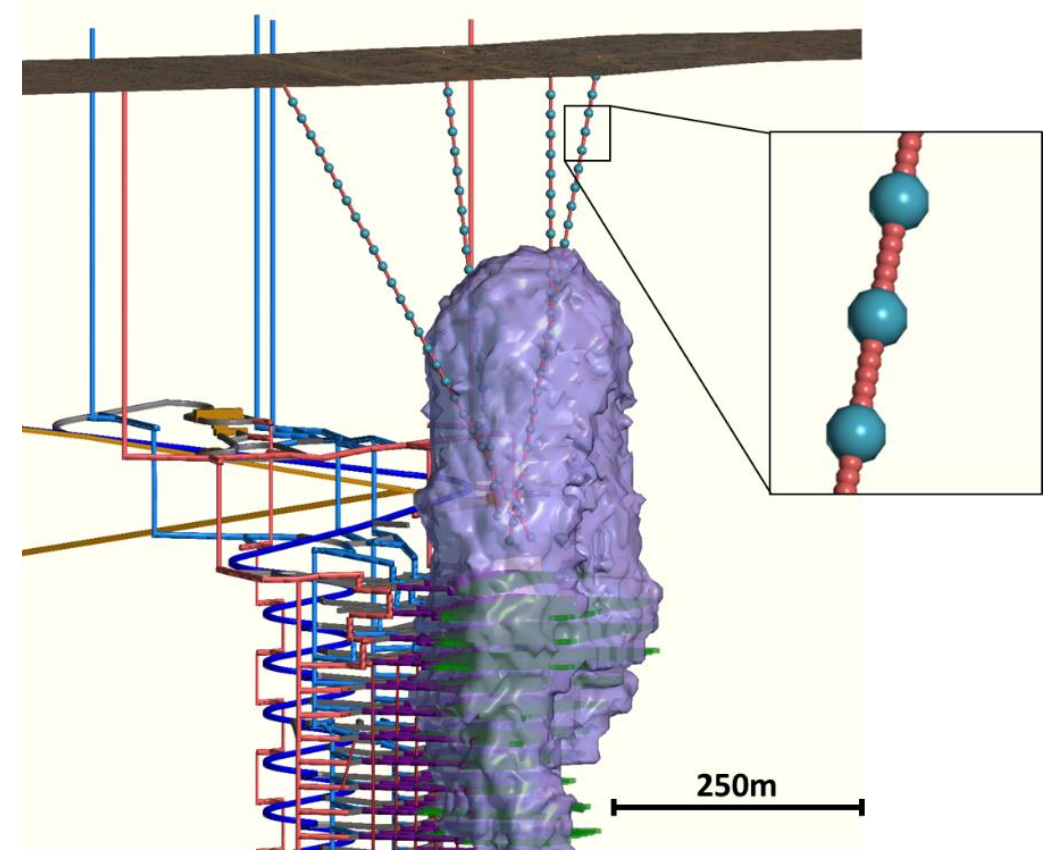

Figure 9 The modelled cave geometry and generalised mine layout showing the proposed array of networked smart markers (red) and beacons (blue) installed within surface boreholes. Isometric view orientation west-northwest 


\subsubsection{Elexon cave tracker markers}

There are several markers on the market that will be useful for the measurement and calibration of the flow parameters of the rock. Elexon cave tracker markers have recently been established as a method for tracking the flow and cave propagation at Argyle mine (Whiteman et al. 2016). These markers can be tracked in real time and are effectively a spinning magnet, which, when spinning, can be located in the cave column. By placing these markers throughout the cave, the movement of the muck pile can be understood better, leading to better flow modelling through calibration. In addition, these markers will allow a better interpretation of the cave back, which, in the authors' opinion, is essential for calibration of flow markers. Tests will need to be undertaken to ensure markers are placed within $150 \mathrm{~m}$ of sensors, and low levels of magnetite within the orebody won't impact on markers being read.

\subsubsection{Metso smart tag markers}

In addition to Elexon cave markers, it is postulated that a smaller marker will be useful for flow monitoring programs. One such marker that will be used is the small version of the Metso smart tag shown on the right in Figure 10. Larger versions of these markers were used to determine stockpile resonance time at Northparkes mines (Jansen et al. 2009). Because of the price and durability of these markers, a large number can be placed inside the cave. The markers are passive radio frequency tags and can be picked up on the conveyor belt.

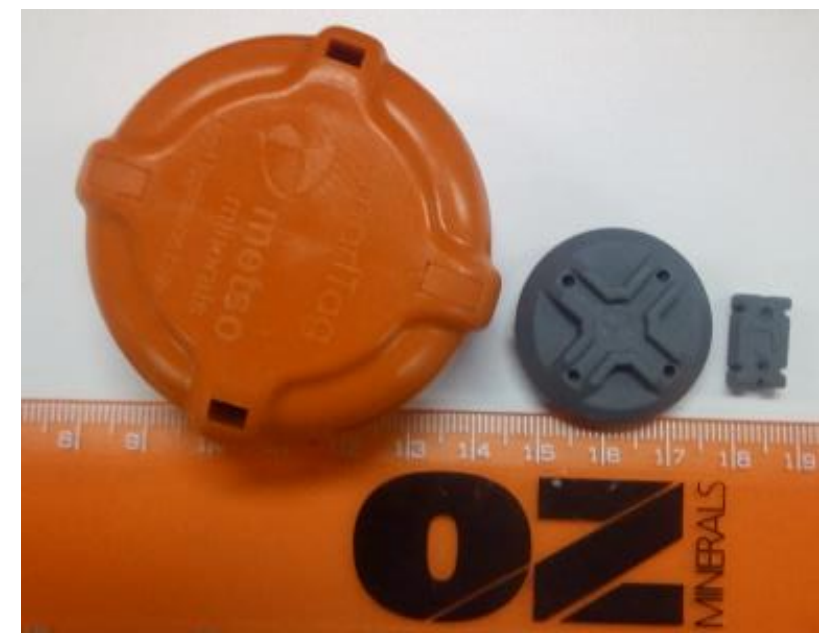

Figure 10 Examples of the Metso markers to be used at Carrapateena

\subsubsection{Grade and lithology markers}

The variability of grade and lithology can be tracked and reconciled through time as another calibration point for flow modelling. A detailed plan of reconciling the block model with development, and then the production bogging, will improve model calibration.

\subsection{Rock characterisation}

Initial analysis has shown that the overlying strata will break up more than the ore. Analysis by others (Pierce 2010; Hashim \& Sharrock 2012) has shown that fine material will propagate through the muck pile faster than coarse material. For a variety of assumptions, initial modelling shows that, unmanaged, this may be a problem. Therefore, further work needs to include additional testwork to further assess this risk and detailed monitoring as described below. 


\subsubsection{Mud rush characteristics of rock}

Vallejos et al. (2017) outlines a procedure for characterising the flow of mud for mining materials at different moisture levels using an Abrahams cone. This procedure could be used to characterise the overlying strata, and therefore, to develop TARPs to manage the mud rush risk at Carrapateena.

Further testwork is also required to understand how the different rock units would break down when saturated with water, such as a slake durability test, or repeating the testwork with water applied.

\subsubsection{Data collection during production}

During production, there are a number of data sources that can be utilised to assess dilution and to manage risk. These include:

- Measuring the marker data and calibrating flow models to correlate with marker observations.

- Measuring fragmentation.

- Measuring the mineralogical make up of fine components to determine if they come from overlying strata.

- Completing a water balance.

- Tracking water through the cave to give a historic account for management.

- Measuring pumping data and rainfall data to determine correlations.

- Measurement of cave geometry and subsidence zone for potential rainfall catchment and geotechnical model calibration.

\subsubsection{Development of triggered action response plans}

There are a number of different classifications used for measuring mud rush risk at various mines. An example of a mud rush TARP is shown in Table 2. Given the large proportion for mine material $(<1 \mathrm{~mm})$ expected, this would need to be revised based on further testwork. A number of procedures need to be developed around these TARPs, and they will need to be updated to ensure safe management of this risk. Awareness, training, buy-in and compliance to the TARPs by the operations team will be required for success in daily mining activities.

Table 2 Deep Ore Zone wet muck classification (Widijanto et al. 2012)

\begin{tabular}{llll}
\hline \multicolumn{4}{c}{ Material size $>\mathbf{5 c m}(\mathbf{M})$} \\
Wetness/water content & $\mathbf{M}>\mathbf{7 0 \%}$ (coarse) & $\mathbf{3 0 \%}<\mathbf{M}<\mathbf{7 0 \%}$ & $\mathbf{M}<\mathbf{3 0 \%}$ (dominated by fine grain) \\
\hline$<8.5 \%$ (dry) & A1 & B1 & C1 \\
$8.5-11 \%$ moist & A2 & B2 & C2 \\
$\geq 11 \%$ wet & A3 & B3 & C3 \\
\hline
\end{tabular}

Green $=$ any loader. Yellow $=$ any loader with supervision. Red = automated loader

\section{Conclusion}

Based on the rock mass units discussed and the typical behaviour of caving operations, a substantial amount of monitoring is required to ensure the safe operation of a cave up to and beyond the propagation of the cave to the surface. Given the weak rock masses observed through this early experimental campaign, several actions need to be set up to ensure the risks of mud rush and dilution can be managed. The modern operation of cave mines can utilise a number of monitoring techniques not available 10 years ago, and these should be considered together with an understanding of the key risks of the operation. 
A method for understanding the breakage of rocks, using a simple cement mixer and sieve, has been shown to be effective for determining how rocks will break. This was demonstrated through a series of low-energy impacts while rotating the material for set periods. This typically has shown a linear increase in fines generation with an increasing number of rotations (or the amount of energy applied). Further study and measurement at Carrapateena and other cave mines will be required to understand and model fines within the cave column. This information can then inform the placement of markers in the cave, in order to ensure flow models can be understood and calibrated, and to inform interpretation of measured fines generation through a caving muck pile.

Based on this early work, understanding the flow and potential mud-forming capacity of the overlying strata will be key for managing the mud rush risk at Carrapateena, and enable successful and safe long-term operations.

\section{References}

Awachie, SEA1983, Development of Crusher Models Using Laboratory Particle Breakage Data, PhD thesis, The University of Queensland, Brisbane.

Butcher, R, Stacey, TR \& Joughin, WC 2005, 'Mud rushes and methods for combating them', The Journal of South African Institute of Mining and Metallurgy, vol. 105, December 2005, pp. 817-824.

Diering, T 2016, 'Modelling fines migration in PCBC', Cave Mining Forum - Workshop 2, viewed 21 April 2018, http://www.caveminingforum.com/library/fines-migration-modelling-pcbc/

Hashim, MHM \& Sharrock, GB 2012, 'Dimensionless percolation rate of particles in block caving mines', Proceedings of MassMin 2012, Canadian Institute of Mining, Metallurgy and Petroleum, Westmount.

Itasca International, Inc. 2018, REBOP, computer software, Itasca International, Inc., Minneapolis, https://www.itascainternational.com /products/software/consulting-software\#rebop

Jakubec, J, Clayton, R \& Guest, A 2012, 'Mudrush risk evaluation', Proceedings of MassMin 2012, Canadian Institute of Mining, Metallurgy and Petroleum, Westmount.

Jansen, WJ, Morrison, R, Wortley, M \& Rivett, T 2009, Tracer-based mine-mill ore tracing via process hold ups at Northparkes mine, Proceedings of the Tenth Mill Operators Conference 2009, The Australasian Institute of Mining and Metallurgy, Melbourne.

Laubscher, DH 2000, Block Caving Manual, prepared for International Caving Study, Julius Kruttschnitt Mineral Research Centre and Itasca Consulting Group Inc., Brisbane.

Napier-Munn, TJ, Morrell, S, Morrison, RD \& Kojovic, T 1996, Mineral Comminution Circuits: Their Operation and Optimisation, Julius Kruttschnitt Mineral Research Centre, Brisbane.

Narayanan, SS 1985, Development of a Laboratory Single Particle Breakage Technique and its Application for Ball Mill Modelling and Scale Up, PhD thesis, The University of Queensland, Brisbane.

OZ Minerals 2017, Carrapateena Feasibility Study Update, OZ Minerals, Adelaide, viewed 8 July 2018, http://minerals.statedevelopment.sa.gov.au/_data/assets/pdf_file/0007/296458/20170824_OZ_Minerals_Carrapateena Feasibility_Study_Update.pdf

Pierce, M, Weatherly, DK \& Kojovic, T 2010, 'A hybrid methodology for secondary fragmentation prediction in cave mines', in Y Potvin, Proceedings of the Second International Symposium on Block and Sublevel Caving, Australian Centre for Geomechanics, Perth, pp. 567-581.

Power, G 2018, Power Geotechnical Cellular Automata Code, computer software, Power Geotechnical, Brisbane, http://www.powergeotechnical.com/software/pgca/

Regan, R 2006, Guideline for Managing the Risk of an Airblast in an Underground Mine, NSW Department of Primary Industries, Maitland.

Smith, M 2017, Carrapateena Project Mineral Resource Restatement and Ore Reserve Statement, OZ Minerals, Adelaide, viewed 7 July 2018, https://www.ozminerals.com/uploads/docs/170824_ASX_Release_Resource_and_Reserve_Statement__Carrapateena_August_2017.pdf

Vallejos, J, Basaure, K, Palma, S \& Castro, RL 2017, 'Methodology for evaluation of mud rush risk in block caving mining', The Journal of Southern African Institute of Mining and Metallurgy, vol. 117, no. 5.

Whiteman, D, Talu, S, Wilson, M, Watt, G, Van As, A \& Kuiper, P 2016, 'Cave tracker flow monitoring system installation at Argyle Diamond Mine', Proceedings of MassMin 2016, The Australasian Institute of Mining and Metallurgy, Melbourne, pp. 479-488.

Widijanto, E, Sunyoto, WS, Wilson, AD, Yudanto, W \& Soebaria, L 2012, 'Lessons learned in wet muck management in Ertsberg East Skarn System of PT Freeport Indonesia', Proceedings of MassMin 2012, Canadian Institute of Mining, Metallurgy and Petroleum, Westmount. 